$\mathrm{Oz}$

Volume 34

Article 3

$1-1-2012$

\title{
Mind the Gap
}

Jane Hall

Giles Smith

Follow this and additional works at: https://newprairiepress.org/oz

c) (1) $(9$

This work is licensed under a Creative Commons Attribution-Noncommercial-No Derivative Works 4.0 License.

\section{Recommended Citation}

Hall, Jane and Smith, Giles (2012) "Mind the Gap," Oz: Vol. 34. https://doi.org/10.4148/2378-5853.1499

This Article is brought to you for free and open access by New Prairie Press. It has been accepted for inclusion in Oz by an authorized administrator of New Prairie Press. For more information, please contact cads@k-state.edu. 


\section{Mind the Gap}

\section{Jane Hall and Giles Smith}

Assemble

\section{Opportunity}

Assemble is a young practice with a background in a range of disciplines: architecture, film, electrical engineering, carpentry, and stone carving, to name just a few. Our first project, the Cineroleum, turned a roadside site into a cinema while our second, Folly for a Flyover, was more ambitious, bringing activity to a space below a motorway on the Olympic fringe. We had begun to notice disused space around London, sites created by recession, failed development, or decline in industry. Those touched by infrastructure seemed prolific and more importantly, accessible. The coincidence of both projects being built beside roads nevertheless produced very different results that forced us to question the city we live and work in. Our work has always begun with the site, the location and history then informing the program. This process, we believe, is vital for a young generation of designers interested in improving the built environment.

By reimagining these spaces through their occupation, we discovered that our work could encourage others to make use of available defunct space. Physical occupation and activity, in most respects, are more important than the built intervention. The building practice we have developed is very experimental. An enthusiasm to realize projects that are overlooked by industry and the relationship they have with their sites is key. Infrastructure has united our projects and continues to be an unexpected inspiration for our work.

\section{Driving in the City:}

Automobility in London

We are an automobile culture. In his Mythologies, Roland Barthes referred to the car as "the exact [contemporary] equivalent of the great Gothic cathedrals." Under the influence of the modern infatuation for automobiles, our cities and landscapes were all formed or adapted to their module. In our postmodern society, automobility became even more complex even as it has been criticized for its opposition, as "traveller's space,"' to the places engendering normal social interaction. It seems to us-a twenty-first century generation of designersthat this postmodern critique is simply reactionary: that "traveller's space" can have the capacity to enable "deeply human encounters." The increasingly redundant infrastructures of yesterday's utopia can be the location of today's experimentation.

It may seem like an obvious point to make, but London was not originally an automobile city. It has had automobility imposed upon it and this strongly colors the urban relationship to cars and their infrastructure. London is a city filled with the scars of collisions between existing trajectories and automobile ones.

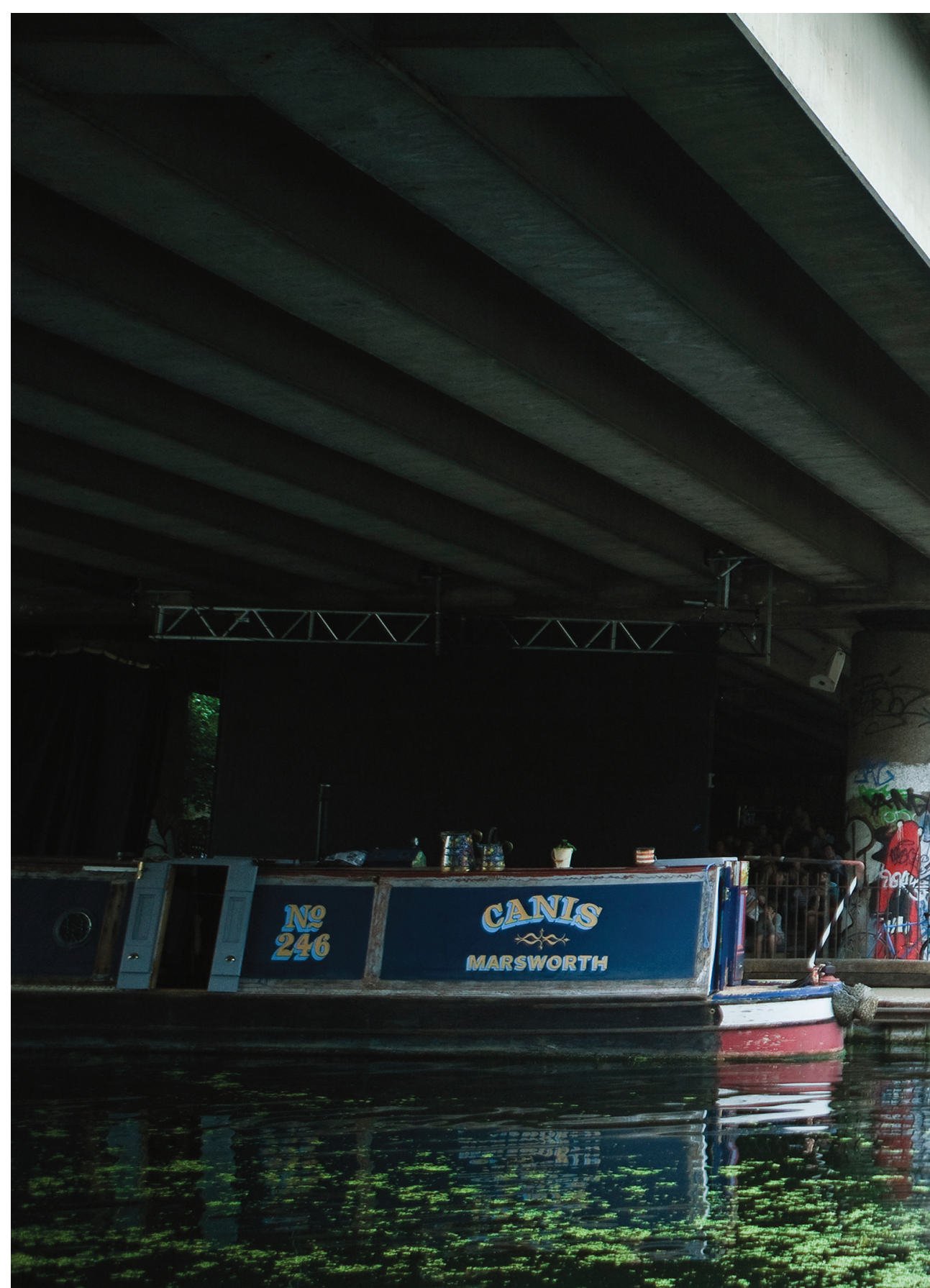



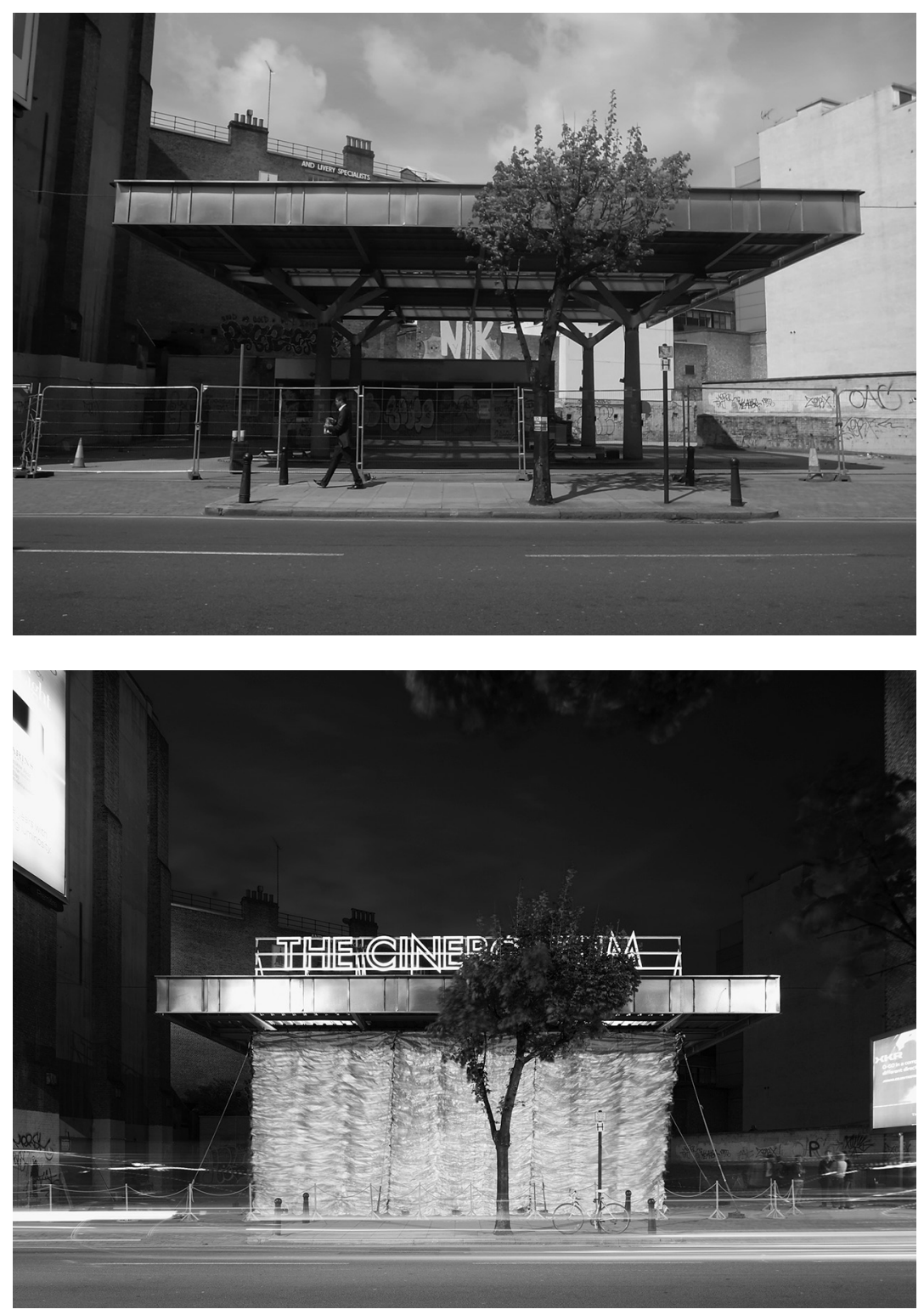

We did not seek out originally as a practice to specifically engage with infrastructures. In many respects our engagement with infrastructural sites appears to be coincidence. However, the large-scale degeneration of the petrol station as a typology ${ }^{4}$ informed our decision to establish our first project within one. our lack of logistical ability) had to be "non-places": the spaces that no one else would touch. The undercroft is in some ways similar-it certainly is a non-place, but is disused in a different way than the petrol station. The petrol station was once vibrant, a space of near-24-hour activity; the undercroft was disused from its inception. In this way the two projects approach two similar but distinct problems for the designers in the post-auto-infrastructural city: one, how one responds to the dereliction of redundant automobile typologies; and two, how to react to the leftover non-places formed in the very act of infrastructural creation.

\section{At the Drive-In:}

\section{The Cineroleum}

Built in the summer of 2010 - and running for a four-week period - the Cineroleum was a temporary cinema that inhabited a petrol station forecourt and the area that had previously been its associated shop. As we have already described, the opportunity was born out of the disuse of the site. We benefited from the financial climate slowing down the progress of the proposed mixed-use development destined to replace the petrol station.

The initial impetus behind allying the two typologies of cinema and petrol station was the phenomenon of their parallel decline. They had simultaneous golden eras, the picture palaces and the motorcars of the 1930s occupying a high water mark in our collective cultural consciousness. That their demise should mirror each other was a fact that we thought we could explore through combining them: our designs reached back to borrow the language of the picture palace to subvert and humanize the tough modern language of the petrol station.

One cannot discuss the Cineroleum and its successes without touching on the methodology of its construction. It was built in a matter of weeks by almost one hundred volunteers. This willing and vital occupation of the site was a telling contribution in imbuing it with a human atmosphere that persisted through its short run as a cinema. In our minds this act of construction was the first step in the process of creating a set of illusions that brought this common infrastructural typology into the realm of everyday human experience. The Cineroleum was situated on one of the main arterial routes through the city and its grandest illusion was removing and then dramatically reintroducing the road to the audience's experience. This was achieved through the theatrical device of the curtain, which was lowered to create the cinema and raised during the credits of the performance to reveal the close proximity of the road. It was this device that choreographed the audience's reaction to the site and transformed it from a petrol station into a theater and back again, all in the course of an evening. 


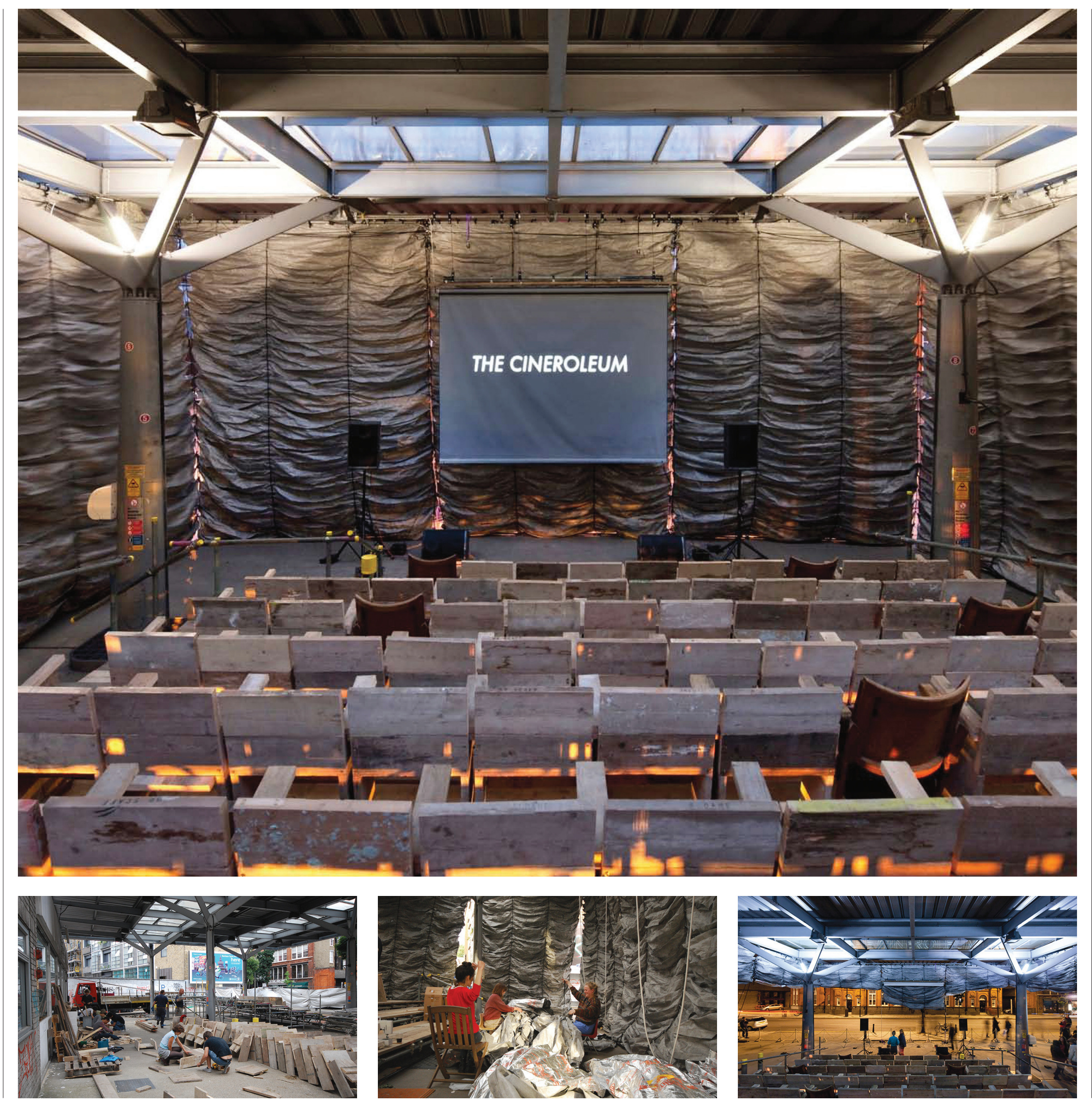




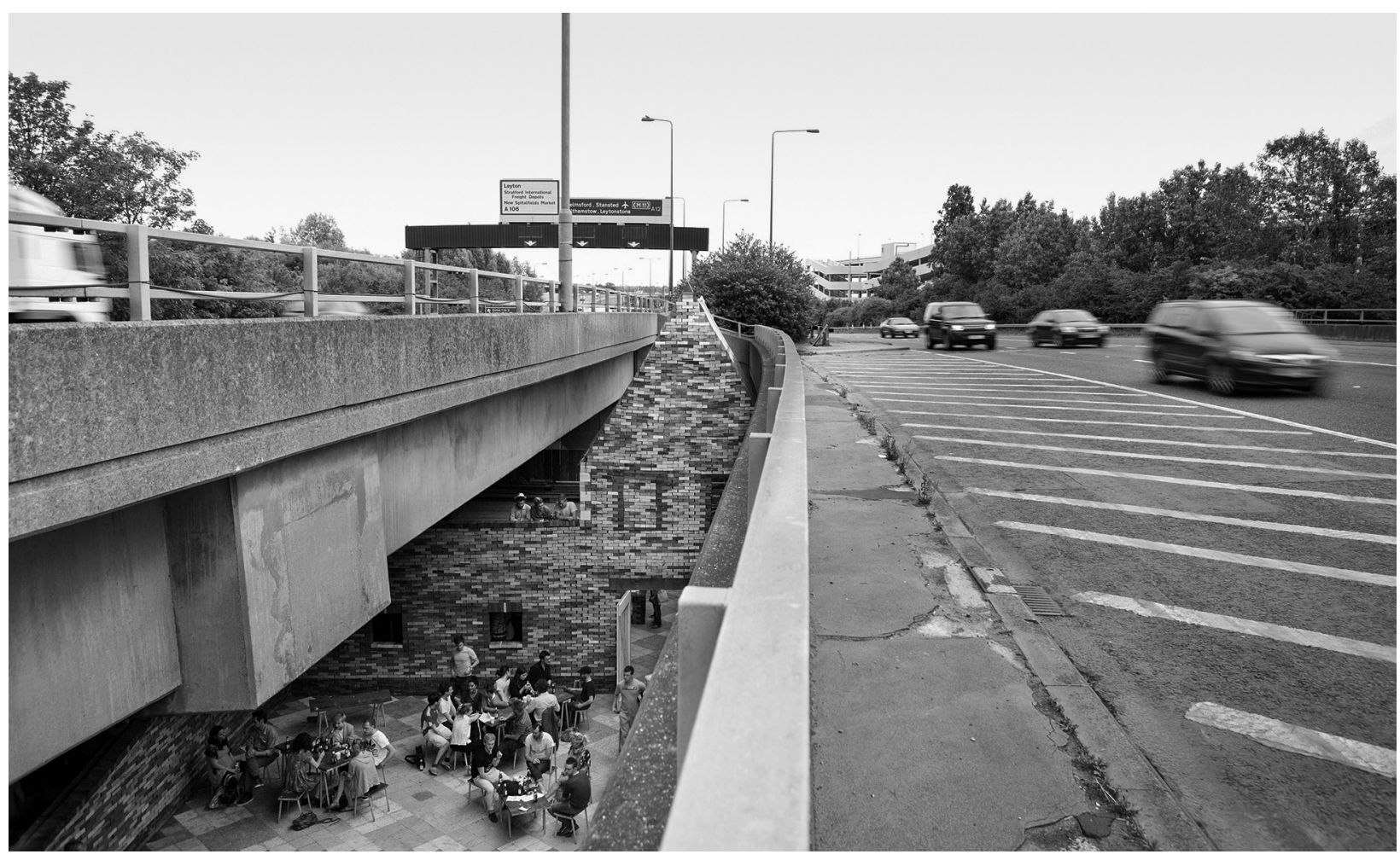

Beneath the Road:

Folly for a Flyover

Our second project, Folly for a Flyover, was built beneath the A12 motorway in a narrow space created by a divide in the road. The flyover separates inner city suburbia from light industry in the East End. Local brick buildings allude to the area's industrial heritage while contemporary occupation reflects the presence of artists due to the numerous, low-cost live/work units. Despite being a relatively isolated part of EastLondon, this area has a vibrant and layered community. However, as with many large sections of infrastructure, the road that to a sense of isolation. Separating the community from Hackney Central, the green space of Mabley Green, and Hackney Marshes, the junction between the road and the Lea Navigation canal is a barrier to the city beyond.

Cast in the shadows of the concrete above, the site had never been the recipient of a holistic design or subsequent formal occupation. The space had been entirely overlooked, playing host to a traveling community and a plethora of local graffiti artists. Despite its proximity to the new Olympic Park, the local authority had not claimed this particular infrastructural space purely so that they would not have to to be a curiosity, made to seem as if it predated the flyover: a collision between existing parts of the city and the large infrastructural projects that had swept through London. The illusion of the Folly as an older building lent it a fictional past, embedding it in the site as a local relic by mimicking local brickwork and the semi-domestic scale of buildings in the area. Our design attempted to intertwine the exterior and interior spaces of the existing flyover with our structure. The most striking and attractive feature of the site was the strip of light that fell through the gap in the road onto the ground below. Emphasizing the unusual curve and tilt of the road, reflections of rippling water from the canal beneath were cast on the soffit. This intersection between the road and canal-two bits of infrastructure that have largely shaped the wayLondon has developed-provided a point of departure for us to begin the narrative that lead to the design and construction of the Folly. We intended that, through occupation, nuances that the road had inadvertently created would become apparent to a wider audience, reclaiming the undercroft as a positive space amongst its industrial surroundings.

The Cineroleum began as a conversation about reuse and how we are able to change our perception of space by reprogramming sites. The Folly, in comparison, looked at the potential of occupation as a catalyst to humanize and claim ownership of these types of spaces. Open every weekend for three months, the site hosted plays, workshops, films and a cafe; there was 


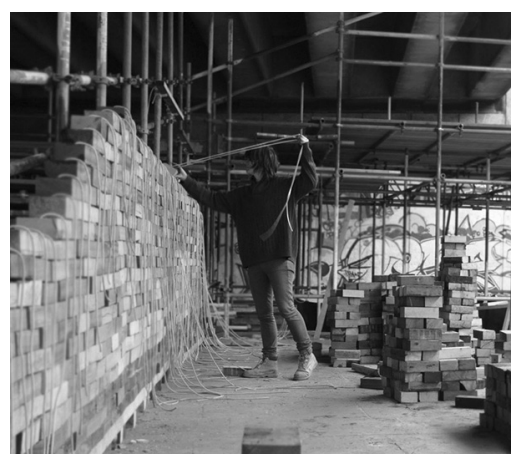

no single program. Our heuristic approach - not just to the Folly but also to the surrounding site-enabled a dialogue about ownership between local users of the canal and its adjacent towpath. What could the long-term use of this structure be? And what was needed to make this non-place a destination? People's appropriation of the Folly into the community could be used to inform the longer-term occupation of the site. It brought more attention to the road and its physical imposition on the city and began, with its proximity, to suggest that a more positive relationship might be possible.

\section{After Infrastructure?}

The two projects were different ways of reinterpreting the austerity of infrastructural spaces, and so, almost inevitably, the question we've been asked the most is, "Can this be replicated? Or, to what extent can these two projects be seen as a model for both small-scale building practice and the humanization of infrastructure?
Firstly, both projects are really quite bespoke; we devised highly situated responses to quite specific spaces. Both sites were slightly extraordinary examples of their infrastructural typology: both the petrol station and undercroft had a latent poetry to them. In these terms, would the specific responses we devised for them be appropriate for other instances of the same typologies?
The other difficulty is that London's infrastructure is a highly specific condition. These projects would flounder in the sprawl of an American infrastructural network - they are the products of highly dense, urban colonization. We are also at a key moment in London's infrastructural development. It seems to us that London is reaching infrastructural saturation-particularly above-surface. While there might be lessons to take from these projects in terms of developing infrastructure, I fear they have little relevance or application beyond their original purpose.

In spite of this, these projects remain as innocent, evocative, and, at times, transformative approaches to the problem of infrastructure. We hope that, in the most humble way, they have had an impact on the everyday life of Londoners.

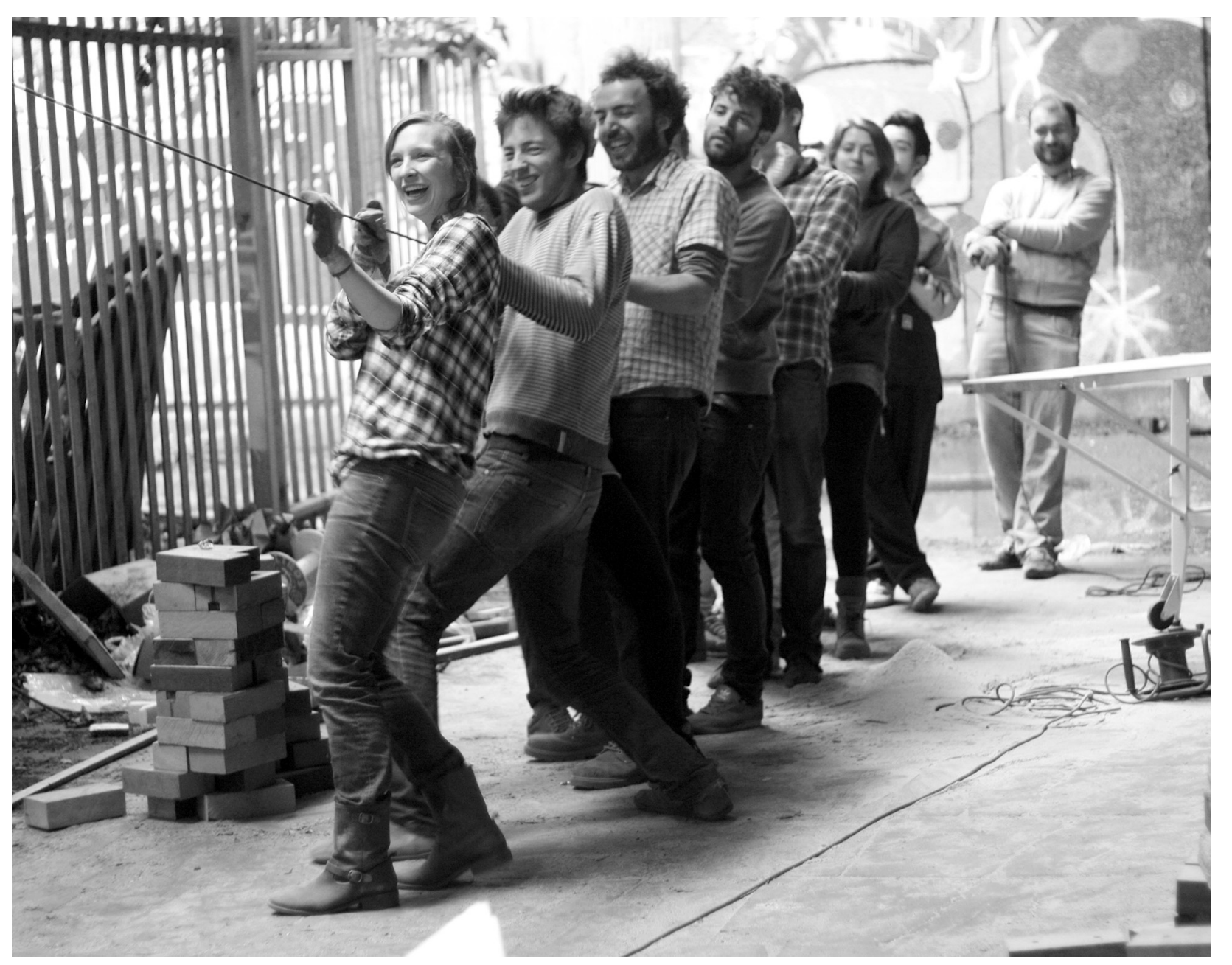




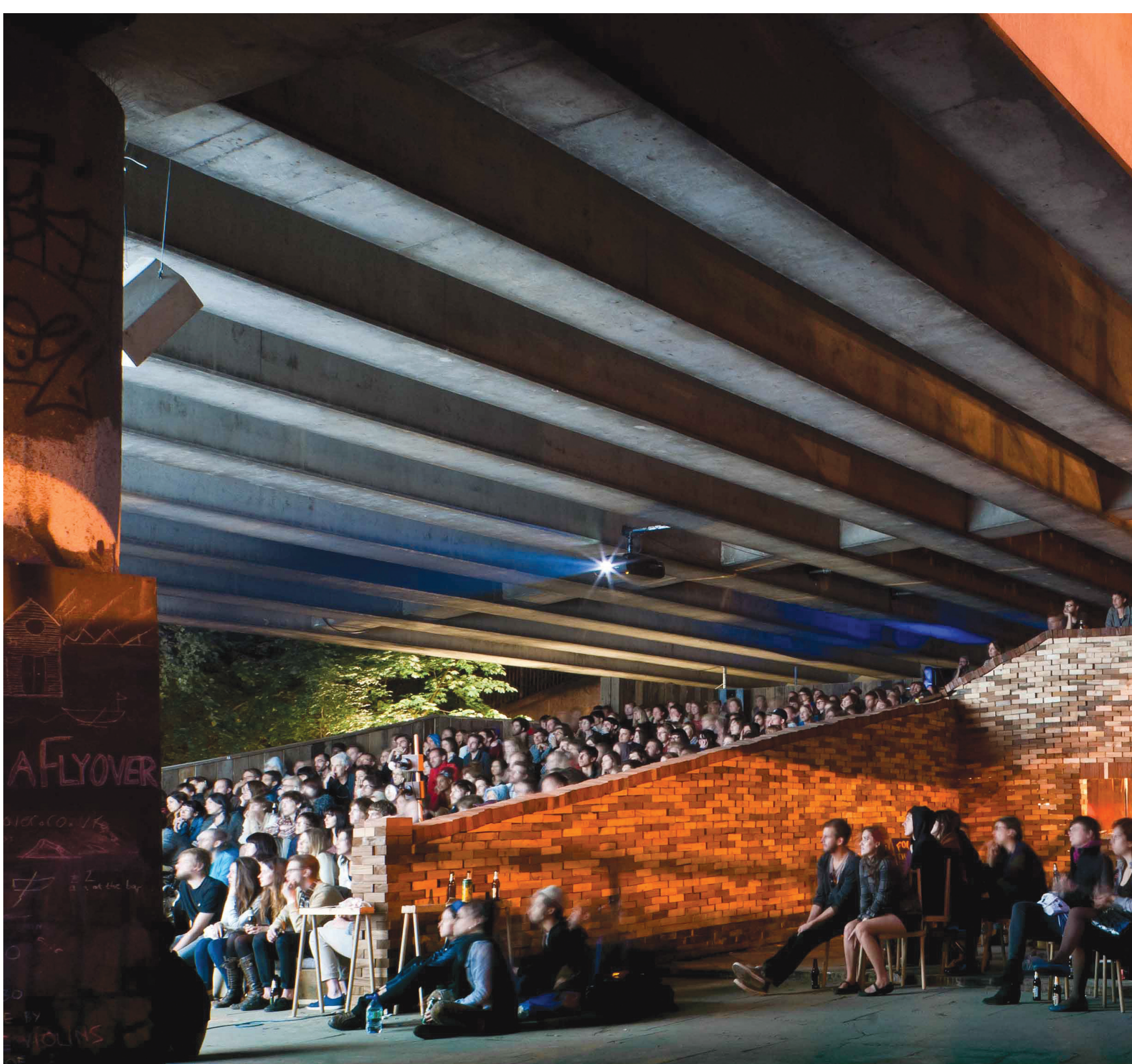




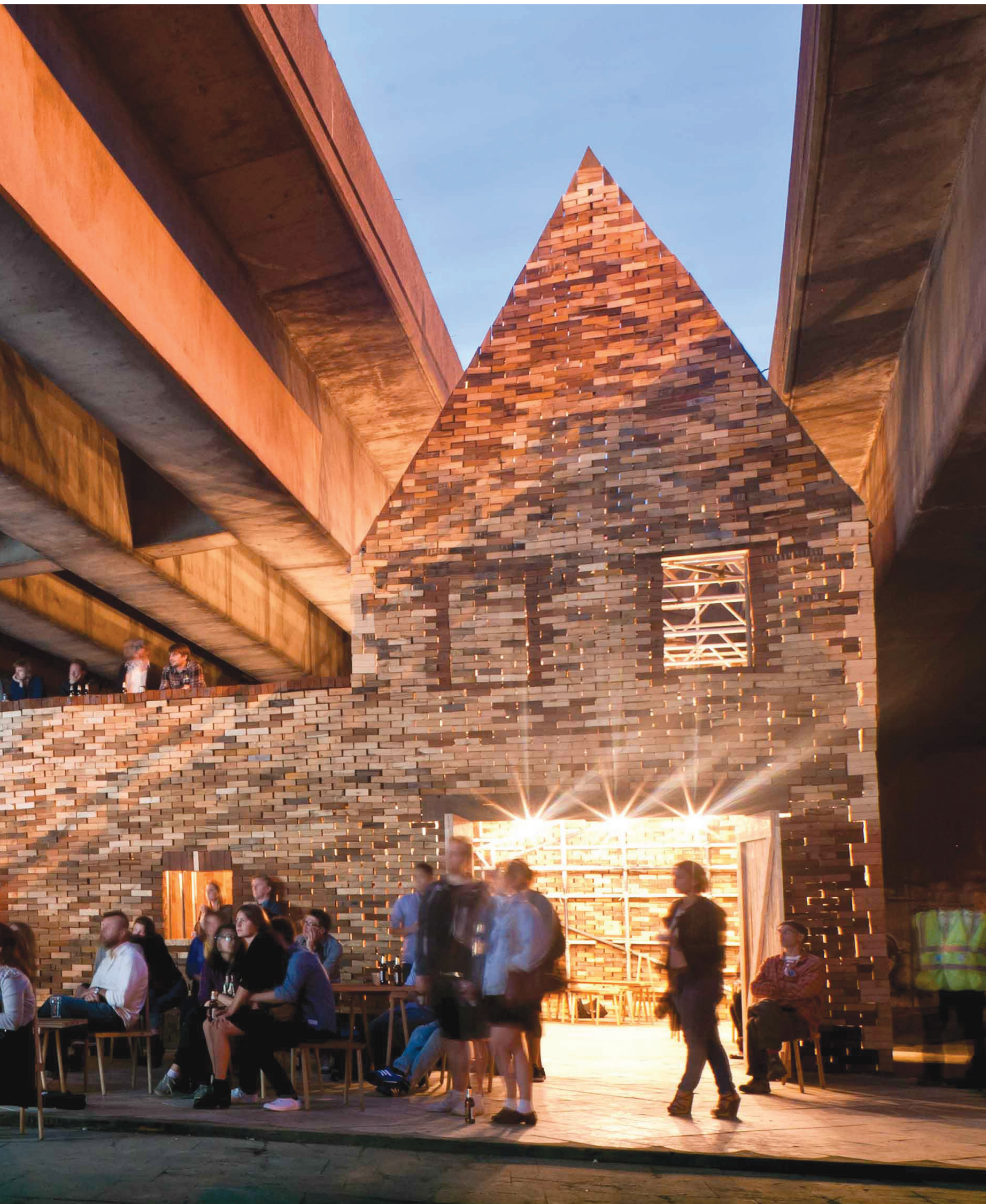

Notes

1. Barthes, Roland, Mythologies, translated by Jonathon Cape Ltd. (London: Jonathon Cape, 1972)

2. "Traveler's space" is an idea of Marc Augés equivalent to his "non-place" and therefore in opposition to the situated 'place' of postmodernity.

Augé, Marc, Non-Places: Introduction to an Anthropology of Supermodernity, translated by John Howe, (London: Verso, 1995)

3. Tuan, Yi-Fu, Space and Place: The Perspective of Experience (London: Edward Arnold, 1977)

4. There are fewer than 10,000 petrol stations left today, out of 74,000 in 1974.

Webb, Tim, "Farewell to Forecourts: Fewer than 10,000 British Petrol Stations are Left," The Independent, 12th February 2006

5. Augé, 1995

\section{Image Credits}

Fig. 1: David Vintiner

Fig. 2: Assemble

Fig. 3: Zander Olsen

Fig. 4: Morley Von Sternberg

Fig. 5-6: Assemble

Fig. 7: Morley Von Sternberg

Fig. 8-11: Assemble 